\title{
URBAN-RURAL: “TIBURTINO" DISTRICT IN ROME AND RURAL VILLAGE "LA MARTELLA" IN MATERA AS EMBLEMATIC CASES OF SETTLEMENTS DURING THE ITALIAN RECONSTRUCTION
}

\author{
R. Pontrandolfi ${ }^{1, *}$ \\ ${ }^{1}$ Architecture Department, Roma Tre University, Rome, Italy - raffaele.pontrandolfi@uniroma3.it
}

Commission II - WG II/8

KEY WORDS: Minor historical heritage, Architectural Neorealism, Italian modern architecture, U.N.R.R.A. Casas, INA Casa, Urban-rural, Architectural recovery and Enhancement, Organic Architecture

\begin{abstract}
:
The architectural and urbanistic events of the Reconstruction in the post-World War II period in Italy are still today a topic of great relevance that deserves to be examined in depth, especially in relation to some examples of historical-testimonial value present, in particular, in the U.N.R.R.A. Casas (1947-62) development/project and the INA Casa Plan (1949-63). The revision of the principles of the modern movement in many construction experiences, established a sort of break in favor of an attempt to reinterpret the architectural tradition in a contemporary and local key so as to respond to the needs of local communities, through the use of a moderate and authentic language that represented them. In this sense, the trend of Italian Architectural Neorealism constitutes an event and an experience of great interest. The re-reading of that season deserves to be examined in depth through the analysis of two of the most emblematic cases: the "Tiburtino" INA Casa district in Rome (194954) and the "La Martella" U.N.R.R.A. Casas rural village in Matera (1951-55). In the two case studies, the dichotomy between urban-rural is underlined by the experimentation of new urban practices from an organicist approach, innovative typological aggregations and the search for a common language that would adopt the canons of the vernacular tradition with the efficiency of pre-war functionalism. The differences, but also the similarities, between the two cases will be analyzed in this contribution both from an urbanistic and typological-architectural point of view, in reference both to the different design approaches (some of the designers are involved in both experiences) and to the transformations of the two settlements in recent decades. The aim of the research work is to propose hypotheses for a sustainable recovery of the settlements.
\end{abstract}

\section{INTRODUCTION}

1.1 The problem of housing in Italy during the post-World War II period between standardization and tradition

The Reconstruction in Italy in the Fifties, has represented one of the most prolific seasons in the history of Italian architecture over the last sixty years. Architectural Neorealism is certainly one of its most original expressions.

The search for a simple lexicon, through the reworking of a vernacular and populist koiné (Reichlin, 2001), borrowed from Anglo-Saxon influences and models, was to be the essence of a new architectural approach. The main purpose was to provide a "modern home for all", with greater attention towards a solidity of design solutions with respect to local needs and contexts, in discontinuity with the abstract and academic precepts of pre-war Italian and European experiences (Tafuri, 2002; Lampugnani, 2004).

In some forums such as the National Congress for Building Reconstruction (Milan, 1945), different approaches to solving housing issues emerged. On the one hand, Milanese architects such as Franco Albini, Pietro Bottoni, Ignazio Gardella, E.N. Rogers, Giò Ponti and others - followers of the pre-war rationalist tradition and represented by the MSA (Movimento Studi per l'Architettura) - aimed at solving the housing problem through a technological and experimental approach, in particular through the prefabrication and standardization of the building site at the detriment of a shrunken workforce. On the other, the group of the so-called "Roman School", composed among others by Ludovico Quaroni, Mario Ridolfi, Mario Fiorentino, Saverio Muratori, saw the solution of the housing issue strictly linked to the use of workforce and therefore to a traditional shipbuilding approach (Di Biagi, 2001; Raguso, 2010; Tafuri, 2002).

1.2 The crisis of the Modern Movement and the reinterpretation of tradition: from the latest CIAMs to the rediscovery of organic and vernacular architecture

In the polarized debate between the two approaches, a "third alternative" appeared in the Italian and European architectural scenario of the post-World War II period. This trend is represented by Bruno Zevi and APAO (Associazione per l'Architettura Organica) and shared in part by figures such as Luigi Piccinato, Giovanni Astengo and Adriano Olivetti, who supported an "organic" architectural vision, on a human and community scale, in direct correlation with the surrounding environment and with elements of Anglo-Saxon and Northern European influence (F.L. Wright, Alvar Aalto, Lewis Mumford).

In the Post-War period, stereometric grids and the typological union imposed from above were replaced in favor of an approach to the housing problem that, instead, takes into account the history and the surrounding environment. This approach was developed above all through an articulated planimetric layout, a variety of typological solutions and a strong figurative expressiveness in relation to the use of handcrafted materials and construction techniques.

\footnotetext{
* Corresponding author
} 
These prerogatives were inherent in the contemporary international debate on the common failure of the theories behind the Modern Movement, well represented by the crisis of the last CIAMs. A crucial role in this regard was played in the international context by Team X. This organization, composed mainly of young professionals (Jaap Bakema, Shadrach Woods, Alison and Peter Smithson, Giancarlo De Carlo, Ralph Erskine, Aldo Van Eyck, Georges Candilis and Jose A. Coderch, amongst others), strongly believed in the heteronomy of architecture, in an inseparable relationship between itself, history and the physical and natural environment. The individual as such was the target user of this "new architecture", linked mainly to the early modernism of which it criticized the recent internationalist drifts (Raguso, 2010; Sabatino, 2013).

Despite the obvious break with part of the modern current of a functionalist tendency and with the previous refined interventions of Italy's Fascist era, it is possible to find a continuity between the First and Second Post-war period. In particular the reconsideration of tradition in a rural and regionalist key which had already begun in several European countries, especially those of the Mediterranean area, starting from the Thirties (In Italy the exhibition Architettura Rurale Italiana at the VI Milan Triennale of 1936 by Giuseppe Pagano and Guarniero Daniel, La Casa Popular en España of 1930 by Fernando Garcia Mercadal in Spain, both reprised in various initiatives in the aftermath of the Second World War such as the Mostra sull'architettura spontanea at the IX Milan Triennale of 1951, organized by De Carlo).

\section{THE AIM OF INVESTIGATION}

2.1 From the Marshall Plan (1947-51), to the U.N.R.R.A. Casas (1947-62) and the INA Casa Plan (1949-63) interventions

During the Reconstruction period in Italy, in about fifteen years, there were many ventures, especially in the public sector, which were often interconnected through different legal devices.

The answer to the problem of the "home for all" was the subject of a debate that began even before the end of the war. In February 1945 the architect Piero Bottoni, in anticipating the ensuing Fanfani law proposal (The INA Casa Plan, Law n.43 of 24 February 1949) by a few years with a project entitled La casa a chi lavora, proposed the establishment of a national Institute (and not a plan) of social insurance for the construction of houses with the contribution of the workers themselves.

The theme of minimum housing for the masses was tested by the Milanese architect himself only a few years later in his experimental district "QT8" (1946-53), presented at the VIII Milan Triennale, where he applied innovative hygienic and construction criteria based on seriality, prefabrication and use of reinforced concrete. The response to housing needs through the rationalization of the building system represented an approach shared by Giò Ponti and the Milanese architects Irenio Diotallevi and Franco Marescotti, who were also involved in the experimentation on the "existenzminimum" (Di Biagi, 2001; Tafuri, 2002). Such a line of thought was particularly opposed by the circle of Roman designers, supported by Fanfani, aimed, instead, at a massive employment of workforce through a traditional type of building site.

The Italian housing reconstruction process was also stimulated and supported through the ERP (European Recovery Program) of the Marshall Plan, which mainly aimed at funding interventions to help people affected by the recent war events. Thus in 1947 the U.N.R.R.A. Casas (Comitato Amministrativo Soccorso Ai Senza Tetto) was established, whose purpose was to plan interventions throughout the country, particularly in the rural areas of the center-south, islands and north-eastern areas of the peninsula.

This initiative was followed, a few years later, by the establishment of the Cassa del Mezzogiorno (Law n. 646, August 1950) and the start of the so-called Agricultural Reform (Law n. 841, October 1950). This last legislative measure was aimed at redistributing the lands of the farmers' estates (Talamona, 2001).

Thus, several rural settlements were built with collective services and facilities for the inhabitants. Main reference was made to the previous American experiences of the Tennessee Valley Authority during Roosevelt's New Deal after the postWorld War I period (Corsani, 2018). The Fanfani Plan, on the other hand, was to be the largest public intervention in the housing sector with the construction, over a period of two seven-year plans, of medium- tolarge-sized neighborhoods throughout the peninsula (Di Biagi, 2001; Guccione, 2002).

Even today, in many cases, the settlements built are still clearly visible and characterized within the urban fabric. The functional facilities in many cases are, however, often more significant, in terms of quantity and performance levels, than subsequent districts and interventions.

The Roman settlements of "Valco San Paolo" (1949-52), "Tiburtino" (1949-54), "Tuscolano" (1950-60), the Milanese "Harrar" (1951-55) and "Cesate" (1951-57), "Borgo Panigale" (1951) and the "Cavedone" (1957-60) in Bologna, "La Falchera" in Turin (1950-56), "San Marco" in Mestre (1951-61) and the "Isolotto" in Florence (1954) are still emblematic examples of that period (Beretta Anguissola, 1963).

However, many of the rural settlements built by the U.N.R.R.A. Casas and the Reform Authority in the Fifties, generally very small in size, instead underwent the test of time. In many cases there was a progressive disuse and consequent degradation, mainly due to the failure of the prerequisites of the Agrarian Reform, the failure to implement the public services provided and the changed socio-economic conditions already in the years following their construction (Raguso, 2010; Bilò, Vadini 2013).

The "La Martella" (1951-55) and "Venusio" villages (1954-57) in Matera, "Orto Nuovo" in Cutro in Calabria (1950), the semirural nucleus "San Basilio" in Rome (1951), "Porto Conte" (Fertilia) in Sardinia (1951-53), the village "Contesse" in the suburbs of Messina (1949-60) and the villages of "Fucino" in Abruzzo (1953) are some of the various examples present on the national territory. The subsequent national general reform of the Authorities in charge of the realization and management of public building interventions - which will transform INA Casa into GesCaL (GEStione CAse per i Lavoratori) and U.N.R.R.A. Casas into ISES (Istituto per lo Sviluppo dell'Edilizia Sociale) - marked the end of an important season for Italian architectural renewal (Di Biagi, 2001; Bilò, Vadini, 2013). Subsequent urban planning policies in the public building sector marked a progressive break with the previous design prerequisites and intentions. In particular, there was to be a lack of attention for the relationship between public space and private housing and, consequently, a lesser integration between the single nucleus of the district and the city. 


\subsection{The reference handbook for the Reconstruction and the 'hybrid' building site between tradition and prototyping}

At the same time as the new Post-war interventions were being carried out, a new reference handbook was written up for the numerous designers involved throughout the country, with precise instructions and suggestions of an urban, ergonomic and architectural nature.

In the book La scala del quartiere residenziale (1952), Adalberto Libera, head of the technical department of the INA Casa Management, highlighted the close relationship between the house, the district and the city. In this context, the neorealist season in architecture marked a crucial moment in the revaluation of the relationship between design and construction, between place and user.

The contribution of the handbooks became a methodological tool to guide the main urban planning, typological and construction choices of the new interventions. Thus, different orientations were found in relation to the different architectural trends of the period.

On the one hand, the Manuale dell'Architetto (1946), published by the National Research Council (CNR) with the contribution of the United States Information Services (USIS) - edited by Ridolfi, Fiorentino, Zevi, Calcaprina and Cardelli with reference to similar Anglo-Saxon manuals - aimed at a technicalconstructive approach that was less technological and more focused on the search for a national-popular lexicon. On the other hand, Il problema sociale, costruttivo ed economico dell'abitazione (1948), edited by Diotallevi and Marescotti, was related to the line of research on seriality and the typologicalconstructive standardization of the Milanese style, in which prefabricated technological solutions were proposed. These two trends in the field of handbooks were to be partly summarized in the subsequent four handbooks by the INA-Casa Management Office (1949-56), which constituted reference models for contemporary building interventions spread throughout the national territory.

In general, except in rare cases, a typological solution (multistorey houses, condominiums with balcony access, terraced housing and low-rise houses), was preferred, with the exception of a few tower buildings. Also from the point of view of the building site, there was a homogeneous trend in the choices made. A hybrid solution was adopted between masonry construction and structural inserts in reinforced concrete (SAP brick slab), with the search for detailed solutions that avoided prefabrication, based on a handcrafted construction approach, referred to the local traditional characteristics (Poretti, 2002).

\section{THE CASE STUDIES CHOSEN}

3.1 The urban-rural connections in the new settlements: the INA Casa "Tiburtino" district in Rome (1949-54) and the U.N.R.R.A. Casas "La Martella" village in Matera (1951-55)

Despite the different architectural trends of the period, it is clear that there was a fairly common approach among the different tendencies, in favour of the search for a "reconnection" between urban and rural settlements spread throughout the territory. The relationship between city-countryside and urbanperiurban will be approached with partly different aims but attempting a synthesis between the two situations, especially in reference to the forced migration processes of populations (especially from the South) towards the industrial cities of the North. On the one hand, the large INA Casa settlements, close to the large urban centres, where the new inhabitants, from the southern regions and who were employed in the industrial sector, were going to settle. On the other, the creation of rural villages in the internal and depressed areas of the country, mainly by initiative of the U.N.R.R.A. Casas and the Reform Authority, to accommodate the families of the farmers, "the subject" of the interventions of the Agricultural Reform.

In this reference framework, the two emblematic cases of Rome and Matera are of great interest for different reasons, especially because they have been a source of investigation and research into the urban planning policies of the period as well as for the design, typological and language choices and approaches, between tradition and modernity. The reinterpretation of archaic community spaces such as "neighbourhood unity", for example, are reinterpreted in light of the contemporary northern European experiences (Mumford, 1999; Talamona, 2001). With reference to the case of urban settlements, the INA Casa "Tiburtino" district (194954), the first intervention of the Fanfani Plan, became a manifesto of architectural Neorealism. Designed by a team of young architects (M. Fiorentino, F. Gorio, S. Gorio, S. Lenci, C. Chiarini, P.M. Lugli, M. Valori, S. Lenci, C. Aymonino, etc.) and led by the Quaroni and Ridolfi group leaders, the settlement was to become an important test case for other contemporary settlements in Rome. On the other hand, the U.N.R.R.A. Casas village "La Martella" (1951-55), designed by many of the same professional authors of the Roman intervention (F. Gorio, M. Valori, P.M. Lugli with the addition of L. Agati) under the direction of Quaroni who also saw to the urban plan, is considered an example of a rural settlement. These two interventions have been examined first of all because they are both examples of the historicaltestimonial value of the Italian neorealist period, for the historical events that link them and for the urban-architectural solutions that were adopted. In particular, these two cases have many designers in common, they were both realized in the same years, are based on the reinterpretation in a local key of community spaces such as "neighbourhood units", and they provide for the use of local materials and technologies adapted to a national-popular language.

The Roman district (Figure 1) is located in the eastern quadrant of the city, close to Via Tiburtina, but it is deliberately closed off and without continuity from the rest of the town. This urban independence is, however, betrayed by the use of blurred and articulated planimetric solutions, through a multiple typological variation, and by a folkloristic and dialectal use of the architectural language (Tafuri, 1964; Raguso, 2010).

The emphasis on a "pictorial research" to recreate the character of buildings built spontaneously in later times, inspired by seventeenth-century Rome, and the villages of central Italy, is quite artificial and partly fictitious (Quaroni, 1955; Aymonino, 1957; Reichlin, 2001). Despite this excessive variety and heterogeneity in the typological and constructive choices used, this intervention is the first urban experiment of that precise historical period. The use of mixed typologies (multi-storey houses, condominiums with balcony access, terraced housing, tower blocks and star-shaped towers), in fact constituted the stylistic and compositional features of the approach to the urban project, as well as the design of the spaces pertaining to the buildings and the inclusion of commercial facilities and community services. 
In this intervention there is a partial reinterpretation of the experiments of the garden city of the Fascist era (Garbatella, Aniene) with references to some Anglo-Saxon and Northern European settlements of an organicist approach, reinterpreted however with a language that takes up elements and typologies of the Italian vernacular tradition (Reichlin, 2001).

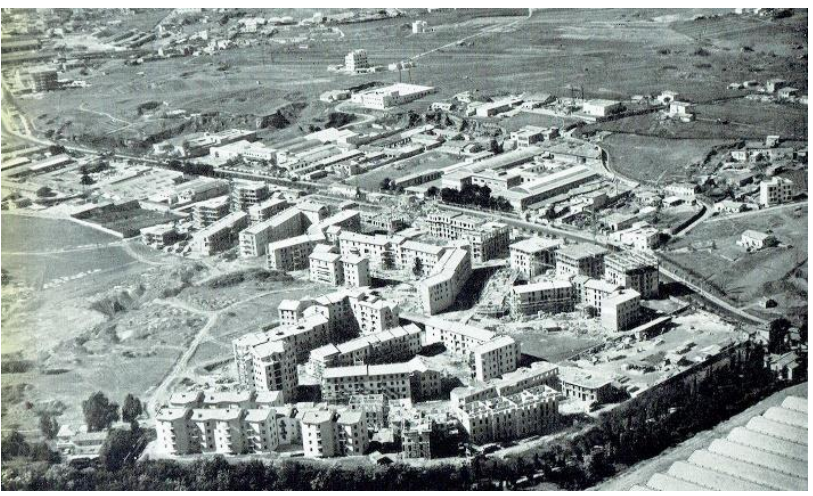

Figure 1. L. Quaroni and M. Ridolfi (group leaders), INA Casa "Tiburtino" district (1949-54) in Rome (@ F. Montuori).

The "artificial realism" present in the "Tiburtino" settlement can be read, for example, in the multi-storey typologies or in the terraced houses with balcony, in the terraced houses with external staircase by Ridolfi, as well as in the courtyards and public spaces that attempt a contemporary reinvention of the neighbourhood (Chiarini, 1957; Gorio, 1957). In this case, some typologies and elements of the minor buildings present in several medieval villages in central Italy (such as the "profferlo staircase" of Todi in Umbria) became reference models for their reworking through a simpler and more contemporary key (Portoghesi, 1958; Reichlin, 2001). One of the most interesting examples to note is certainly the reinterpretation of the traditional housing typology with "external profferlo staircases", taken from minor architecture and reinterpreted here by Ridolfi himself in the terraced building typology with balcony. In this specific case, the architect proposed a spatial development of the stairway-balcony element that allowed for an aggregation of the individual buildings with a slight increase in height, aimed at shifting the composition as a whole. The search for a reinterpretation of popular historical features was to become, starting from this first intervention, the stylistic feature of many other following settlements of the Italian neorealist period, with results that were not always convincing (Tafuri, 2002). A few years after its realization, the Roman intervention was partly criticized by the designers themselves for its "excessive participation" in the choice of stylistic and typological solutions, forgetting instead the real needs and demands of the inhabitants for whom it was intended (Quaroni, 1955; Aymonino, 1957).

The rural settlement of "La Martella" (Figure 2), on the other hand, is the result of a different historical and geographical situation.

The story of the displacement of the Sassi district in Matera, following the visit of President Alcide De Gasperi in 1950, lead to the establishment of a special Study Commission made up of different professionals (F. Friedmann, T. Tentori, F. Nitti, as well as Quaroni and Gorio among others), thanks also to Olivetti's promoting action. This research group was set up to investigate the precarious conditions of the historical settlement and the subsequent hypothesis of the population displacement in rural villages outside the settlement (Musatti, 1955; Acito, 2002; Pontrandolfi, 2002).
Of the six villages originally planned, only four were built ("La Martella", "Venusio", "Picciano A and B"), the most important of which, in terms of size and characteristics, is the case under study. The architect Ettore Stella from Matera, who died prematurely in 1951, was commissioned to draw up a first design proposal where the new village was to be inserted in the Timmari area Subsequently the task was assigned to a group of Roman architects from the Centro Studi per l'Abitazione led by Quaroni, most of whom had taken part in the Capitoline intervention of the "Tiburtino" settlement (Tafuri, 2002; Raguso, 2010). This new experience for the same design group, with the exception of Ridolfi, was interpreted as a chance to escape from any kind of mannerism and to confront a very precise reality whom to give answers regards the primary needs and requirements of the future inhabitants (Tafuri, 1964). The planimetric reference of the urban layout is inspired by British garden cities and American greenbelts, while the typological references try to reinterpret the local rural dwellings. The compositional study of residential buildings with an agricultural annex and animal sheds, as well as the inclusion of vital facilities such as common bakeries, were a direct consequence of the suggestions and requests of the future inhabitants (Bilò, Vadini, 2013; Corsani, 2018). Unlike "Tiburtino", the village "La Martella" is certainly one of the first examples of "participatory planning". Moreover, the rural intervention in Matera differs from the Roman district for the choice in the housing typologies adopted and for the uniform stylistic language. Therefore, a single type of housing, with eleven distributive variants for the farmers and another for the craftsmen, was created and chromatically characterized by a white plaster covering. It is interesting to note how, for example, in the residential typologies intended for peasants, the designers maintained the functional home-installation relationship, present in the Sassi caves, but with some measures to separate the two rooms for hygienic and sanitary reasons (Gorio, 1954; Raguso, 2010). The public services and facilities (civic center, cinema-theatre, post office, church, school buildings, police barracks) and the open spaces were located in a barycentric position.

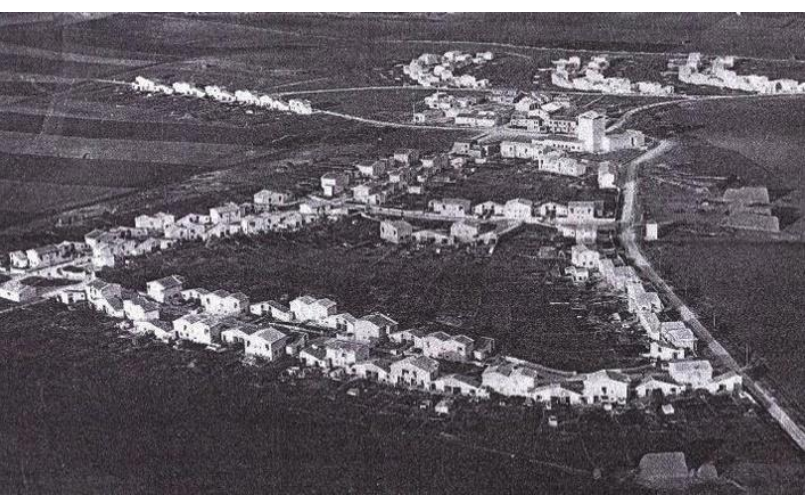

Figure 2. L. Quaroni (group leader), the rural village U.N.R.R.A. Casas "La Martella" (1951-55) in Matera.

The incompatibilities in the approach and management of the intervention between the U.N.R.R.A. Casas and the Reform Authority, together with the changed socio-economic conditions on a national scale and the lack of services and facilities provided originally, lead to a progressive abandonment and degradation of the settlement as well as widespread unauthorized buildings. Moreover, the recent public and private building interventions, carried out in some areas on the outskirts of the existing village in the last twenty years, have drastically changed its original structure (Gorio, 1954; Quaroni, 1981; Bilò, Vadini, 2013; Mininni, 2015). 


\subsection{Main similarities and differences in the two case studies}

It is possible, and interesting, to draw a line of comparison between the two examples of the "Tiburtino" district and the rural village "La Martella", especially for the direct connections, the events and the common protagonists that both interventions had during the Reconstruction period in Italy in the Fifties. As far as the original urban plan is concerned, the considerable difference in territorial extension between the two settlements is noteworthy, also due to the different geographical location compared to the urban centres. The first case has a total area of about 89,000 square meters and has not undergone significant alterations or additions over the decades, with the exception of the heterogeneous surrounding building context on its outskirts, in which it is now incorporated. The village outside Matera, on the other hand, due to its peripheral location with respect to the provincial capital of Basilicata, has a surface area of about 275,000 square meters, excluding the recent Ecopolis and Ater interventions that have visibly modified the planimetric layout as well as the alterations and additions to the original building.

Another difference concerns the inclusion of public facilities: in the Roman district there are in actual fact, only four onestorey buildings for commercial use, while in the rural settlement there is a church, a civic centre with annexed shops and a post office, a cinema-theatre, a clinic, three communal bakeries and three school buildings. This diversity is certainly due to the different functional characteristics of the two interventions: the first is an urban district located today within a consolidated fabric, the second originated and is still an independent nucleus from the town of Matera, about ten kilometers away. Also from the perspective of the residential typologies present in both interventions, there is a clear difference of choices. In "Tiburtino" different aggregative typologies are used, from the multi-storey home, to the terraced house with balcony, from the star-shaped towers to the terraced houses with external staircase.

In the case of "La Martella", on the other hand, it was intentionally chosen to use a single type of housing, with about eleven distributive variations for the residences intended for farmers (single-family terraced house with agricultural annex and stable), and a second different type intended for craftsmen.

It is interesting to highlight how the design and compositional approach differs in some typological choices made by the designers who were involved in both interventions. The building models of the tower houses of Lugli and the in-line Valori typology, both present in the Roman district, were replaced instead by a single "ideal type" with several variations in the case of the village outside Matera.

The chromatic diversity in the building refurbishment of the buildings is another distinctive feature of both interventions, due to a precise ideological choice of the designers. In the Roman intervention the chromatic diversity of the coatings is motivated by a desire to recreate an artificial environment for the future inhabitants, while in the village near Matera the homogeneous treatment with white plaster is almost a "criticism" of the previous urban painting experiment. The different maintenance of the fences and the external spaces pertaining to the buildings is another distinctive feature between the two cases in question. While in the urban district there are multiple finishing elements of different colors and materials, in the village of Matera a simpler and more moderate language was sought, also for the outdoor accommodations, with the walls and fences coated in the same color as the houses.
As already mentioned, the two settlements also differ in the degree of participation that the respective inhabitants had in the design choices. In the first case there was no involvement, but a forced imposition of the types of housing and services; in the second case instead, although with little success, there was an attempt to involve the representatives of the farmers for suggestions on the typological devices and common services to be adopted.

Despite the considerable differences found in the comparative analysis between the two examples chosen, there are also similarities, especially in the use of certain stylistic elements and in the hybrid use of load-bearing masonry and reinforced concrete inserts: the treatment of the footings with local stone, the use of perforated bricks for the ventilation of the attics (in "Tiburtino") and agricultural annexes (in "La Martella"), the "Roman style" type of door-window and other formal solutions used. Moreover, the contemporary reinterpretation of the "neighbourhood unit", even if in different ways, is another common feature between the two cases: in the INA Casa district it is reinterpreted through the creation of central spaces between the typological aggregations, while in the U.N.R.R.A. village it is reconstructed through the open spaces in front of the houses along the streets.

\section{CURRENT SITUATION AND INTERVENTION STRATEGIES}

\subsection{The level of transformation, the state of conservation and the current conditions in the two interventions analyzed}

Almost sixty years after their construction, these two emblematic examples of the Italian neorealist architectural period have undergone several changes both from an urban point of view, in the relationship with the city and surroundings, and from that of the alterations and modifications that have affected the original buildings, as well as some extensions on the settlement fabric.

On the basis of the previous comparative analyses, and the investigations and surveys carried out on the field, it is possible to see a different level of transformation and a consequent level of occupation in the two interventions under examination. In the case of "Tiburtino" there is a good overall state of conservation, also thanks to the subsequent construction of new urban areas around the built-up area that have guaranteed a lesser isolation in the urban context (Figure 3). This level of maintenance can be seen both in the main residential aggregations that make up the district, and in the public and private areas around them, where there are no permanent excrescences, shacks or unauthorized buildings.

On the contrary, in the case of the village "La Martella" the marginal and isolated location has instead brought on a state of widespread degradation and, in some circumstances, a high degree of alteration of the original types. Moreover, the areas originally destined for agricultural plots were progressively occupied by permanent unauthorized structures that compromised the original overall image as well as the new residential interventions, in the north-eastern and north-western quadrants, totally unrelated to the existing village. In particular, with regards the occupation of the agricultural plots behind the farmers' houses, it is interesting to note how, during the construction of the settlement, additional agricultural annexes were originally planned through state subsidies. These premises would later be declared as "livestock premises" (Raguso, 2010). Starting from these additions considered "legitimate", however, over the decades there has been an uncontrolled abuse in the areas 
originally intended as vegetable plots with buildings that have altered, both functionally and figuratively, the overall image of the housing types (Figure 4).

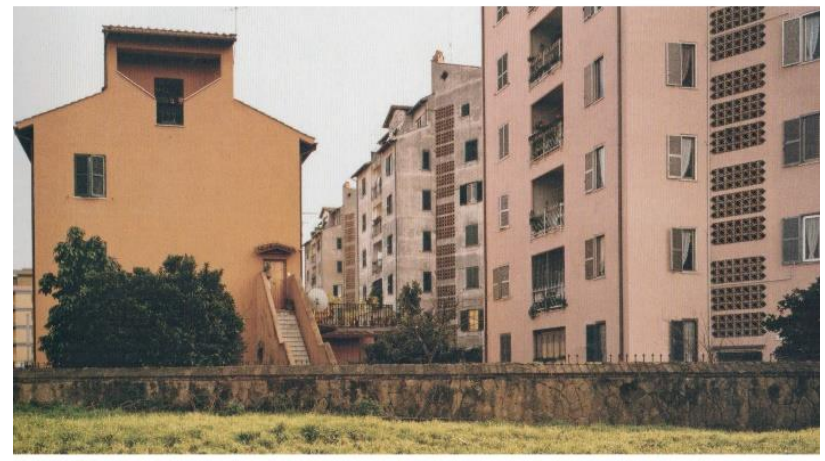

Figure 3. Recent photograph of the current state of conservation at the INA Casa Tiburtino district in Rome.

(C ph. by F. Jodice).

As a direct consequence of the different level of transformation of the two cases under examination, their settlement structure is also very different, with a different degree of awareness and civic sense among the current inhabitants.

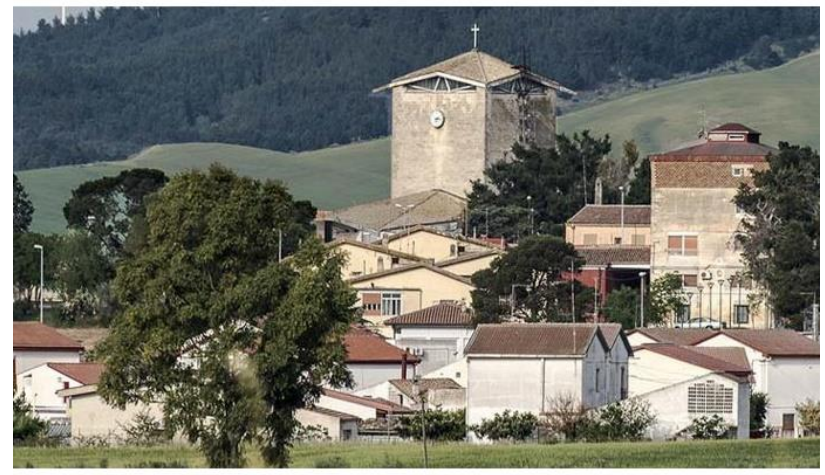

Figure 4. Recent photograph of the current state of conservation of the rural village La Martella in Matera. (@) MiBaC Image Copyright 2018).

4.2 Intervention criteria and strategies for the recovery and rehabilitation of two examples of the historical-testimonial value of public residential buildings in the Post-War period

According to the comparative analyses and direct surveys on the field, it is possible to hypothesize some intervention criteria for the rehabilitation and recovery of settlements such as those analyzed in this contribution. These hypotheses aim at developing more widespread strategies for the recovery, reuse and rehabilitation of public housing interventions of historicaltestimonial value of the Italian Reconstruction period, present in many areas of the country.

It is fundamental, first of all, to reflect on what the main historical-critical criteria and evaluation elements for the selection of examples of historical-testimonial value of the historical period in question may be. For some years now, several research institutes and associations (Olivetti Foundation, Do.co.mo.mo, etc.) have been preparing a list of these criteria for the selection of the most emblematic cases of modern architecture. In particular, first of all, valuable works recognized in the scenario of national and international architecture will have to be taken into consideration, through a special survey of the scientific literature. Secondly, these selection criteria must include all cases that are significant for the evolution of building typology as well as for technicalconstructive experimentation: in particular, for the use of local materials, for typological-compositional innovations and for the building site solutions used. Another selection criterion is related to the importance of the quality level in relation to the context and the users settled there. Therefore, settlements in which a specific relationship with the place can still be read today, in which there is a clear reinterpretation between community public space, areas of collective use and residences, as well as a relationship between urban and rural space, should be prioritized. Finally, this selection must certainly include works designed by at least one important figure in the historical period of reference (AA. VV., 2009).

The different level of transformation of the original building, as well as the different geographical and settlement conditions, suggest some hypotheses and strategies for the recovery and regeneration of the current settlement fabric. With reference in particular to the urban planning instruments in force and the demands of the allocated population, a preliminary study will certainly have to be carried out in order to understand which are the priority objectives for a homogeneous urban regeneration action (Berdelli et al., 2003; Mininni, 2015).

Starting from these premises, it will therefore be necessary to pursue a double objective that aims at a compatible and effective recovery both from the urban fabric and the building point of views. This double level of intervention will be accompanied by specific objectives to be implemented through different approaches, devices and integrated management tools. In the first strategic area, evaluations and analyses of an urban and territorial nature will have to be prepared, with particular reference to what role the investigated settlements cover and/or can assume with respect to the urban or rural area in which they are located. It will be essential to perform studies and feasibility analyses of the public services present both on an urban and community scale, especially in relation to road networks and connections that are either existing or under construction. In order to achieve this objective, the use of geo-referenced digital methodologies and tools such as the GIS (Geographic Information System) will also be an important support, both in the data collection and classification phase and in the decision making phase regarding the strategies to be pursued. With reference to this first level of intervention, the two residential settlements analyzed are two interesting cases especially for their different geographical and territorial location. The "Tiburtino" district, located within the North-Eastern quadrant of Rome, is crossed by one of the main roads, the Via Tiburtina, and is fairly well connected to one of the main metropolitan and railway junctions of the entire city, the new Tiburtina Station. Also in terms of local services, the "Tiburtino" is well served, especially when compared to other more recent Roman suburban interventions.

In the case of the rural village "La Martella", on the other hand, the infrastructural system is still lacking, both on a local level and in terms of connection with the town of Matera. This condition of isolation would require reconsidering the strategies at a territorial level, also in relation to a greater supply of services required by the population settled there. The recent construction of the new state road 655 "Bradanica" is an important precondition for the improvement of the connections between the suburban settlement and the provincial capital. 
A second level of intervention can be attributed to all the recovery and re-functionalization strategies that refer specifically to the existing settlement fabric. Starting from the surveys and investigations carried out on the building heritage, it will be necessary to evaluate the state of conservation of every single building present in each settlement, also in relation to its degree of use. In this perspective, use of digital technologies and tools such as laser scanners, photogrammetry and the development of BIM (Building Information Modeling) models will also be important for a detailed and constantly updated survey.

On the one hand, the requalification of public and pertinent spaces (the original "neighbourhood units") with greater supply of public services and facilities also through the reuse and refunctionalization of existing buildings. On the other, the regular maintenance of individual residential and service buildings, also through retrofitting and energy improvement methods that are not invasive but rather enhance some of the passive measures already present in the buildings.

As far as the "Tiburtino" settlement is concerned, the recovery of public and pertinent spaces between buildings would enhance the wide range of open common areas already present, also through the implementation of neighbourhood services. The "La Martella" village, on the other hand, would, first of all, need a territorial planning that would guarantee a better connection with the city of Matera, also through the recent road networks under construction, in order to overcome the historical isolation from the city that has partly caused its decline.

As far as building restoration works are concerned, especially in view of the historical-landscape protection constraint prescribed by the PRG (General Regulatory Plan) in force, a more effective regulation would be desirable to guide the typological-urban redevelopment of residential buildings and public equipment present. In this case, the demolition of some unauthorized buildings in the vegetable plots, the completion and recovery of collective service facilities, the redevelopment of public spaces and degraded areas still present in the village, together with the development of innovative agricultural policies that reflect their original vocation, should be envisaged. In general, for both cases, as today a large part of the building fabric is privately owned, consensual interventions could be foreseen also through state or regional tax incentives for a homogeneous and coordinated urban-typical redevelopment and recovery action, despite the current excessive real estate fragmentation.

\section{CONCLUSIONS AND FUTURE RESEARCH PERSPECTIVES}

The proposed contribution attempted to analyze and compare two examples of Italian architecture and urban planning during the second half of the Twentieth Century, in this case both from the period of Neorealism in the Fifties. At the basis of this research, two emblematic cases have been identified and discussed that deserve to be investigated and compared above all for their historical-testimonial and paradigmatic value. These chosen interventions can actually constitute an example of research and methodological approach that is also valid for other contemporary settlements, which today make up significant parts of the city and the territory, and which are in need of a coordinated recovery and redevelopment action, according to the new demands of its inhabitants and the current market trends.
In many cases, as in the two examples chosen, it is essential to set up associations and neighbourhood committees with the aim of understanding the real needs and requirements of today's residents, who are often different from those who originally settled there, in trying, on the one hand, to comply with the protection and preservation of the existing housing heritage and, on the other, to respond concretely to the real needs of a refunctionalization and implementation of the services.

In recent years greater interest regarding these settlement realities has grown, also in relation to the need to limit soil consumption and to encourage actions for the recovery and reuse of important parts of the urban and settlement fabric.

With reference to this reconnaissance survey on the existing heritage, the study of the archive sources, the direct survey and the photographic investigation are fundamental as instruments of comparison with the current situation, in order to verify the state of conservation and the level of alteration of the original features for each building. In this perspective, it would be necessary to prepare a digital storage device for this archival information (often heterogeneous), and for the data collected on field through the surveys. This consideration is valid above all in relation to the differences that can be found in the comparison of some technical drawings with the constructions themselves and which were sometimes modified on site.

Various research organizations and institutes (Do.co.mo.mo, ICOMOS, etc.), foundations (Fondazione Olivetti, MAXXI Architettura) and associations, in recent years have taken an interest both in a reconnaissance survey and in preparing guidelines to implement strategies for the enhancement and management of the modern architectural heritage (AA. VV., 2009). However, these criteria for the selection of interventions of a historic-testimonial value that are to be safeguarded and protected will have to take into consideration the needs of the current inhabitants and, above all, assess the willingness of the local administrations to prepare concrete policies for the recovery and regeneration of these settlements. A joint action by institutions, research institutes and archival entities would therefore be desirable in order to plan intervention strategies aimed, on the one hand, at the urban re-functionalization of the settlements in relation to the new needs and, on the other hand, at a more specific recovery and reuse of the original buildings, preserving their valuable features. In this regard, with reference to the two cases chosen, it would be essential to develop a Building Recovery Plan, following the surveys on the existing one, which prescribes precise intervention criteria for each building to be protected and which architectural elements to restore or recover (Berdelli et al., 2003).

In order to pursue these aims in a structured and effective way, it would be fundamental to develop an adequate knowledge in relation also to the joint use of some methodologies and digital tools related to the ICT (Information Communication Technology) field such as GIS and BIM. These two technologies, although they are created for different purposes and refer to different levels of investigation, would be essential both in the analysis and survey phase and in the preparation of recovery strategies on an urban-territorial scale of the building fabric (according to a multiscale approach). Such IT devices and approaches could significantly improve the process of collecting and cataloguing the information found on the cases under investigation, thus providing a basis for the subsequent hypotheses aimed at the recovery and management of modern public housing. 


\section{REFERENCES}

AA.VV., 2009. Strategie di valorizzazione e gestione per il patrimonio architettonico: sguardi e proposte. Collana Intangibili, Quaderni della Fondazione Adriano Olivetti, RomaIvrea.

AA.VV., 1959. Quartiere Tiburtino in Roma, Architettura. Cronache e storia, p. 45.

Acito, L., 2002. Matera '900. Siti, 01, Matera.

Aymonino, C., 1957. Storia e cronaca del quartiere Tiburtino. Casabella Continuità, 215, p. 18-43.

Aymonino, C., 1959. Matera: mito e realtà. Casabella Continuità, 231, p.7-12.

Berdelli, P. G., Capomolla, R., Vittorini, R., (Eds.) 2003. L' architettura INA Casa (1949-1963): aspetti e problemi di conservazione e recupero. Gangemi, Roma.

Bilò, F., Vadini, E., 2013. Matera e Adriano Olivetti. Collana Intangibili, Fondazione Adriano Olivetti, Roma.

Casciato, M., 2000. Neorealism in Italian Architecture. Anxious Modernisms, Experimentation in Postwar Architectural Culture, Williams Goldhagen, S., Legault, R., (Eds.), Mit Press, Cambridge, MA, USA.

Chiarini, C., 1957. Aspetti urbanistici del quartiere Tiburtino, Casabella Continuità, 215, p. 28.

Chiarini, C., Girelli, M., 1959. Dal Tiburtino a Matera, Casabella Continuità, 231, 23-34.

Corsani, G., Cozzi, M., 2018. L'Oltremare in patria. Architetture e paesaggi nei nuovi borghi rurali del secondo dopoguerra in Italia. Borghi rurali e borgate. La tradizione del disegno urbano negli anni Trenta, Corsani, G., Porfyriou, H., (Eds.), Palombi Editori, Roma, p. 232-248.

De Carlo, G., 1954. A proposito di La Martella. Casabella Continuità, 200, p. 5-8.

Di Biagi, P., 2001. La grande ricostruzione. Il piano Ina Casa e l'Italia degli anni '50. Donzelli Editore, Roma.

Fabbri, M., et al., (Eds.) 1982. L'immagine della comunità. Architettura e urbanistica in Italia nel dopoguerra. Casa del Libro, Reggio Calabria.

Giura Longo, T., 2003. Matera: i Borghi e i Quartieri degli anni '50. Siti, 02, Matera.

Gorio, F., 1954. Il villaggio La Martella. Autocriticà. Casabella Continuità, 200, p. 31-38.

Gorio, F., 1957. Esperienze d'architettura al Tiburtino. Casabella Continuità, 215, p. 34 .

Guccione, M., Segarra Lagunes, M.M., Vittorini, R., (Eds.) 2002. Guida ai quartieri romani dell'INA Casa. Gangemi Editore, Roma.
Magnago Lampugnani, V., 2004. The Myth of Reality. Notes on Neorealism in Italy 1946-56. Architecture \& Arts 1900-2004 - A Century of Creative Projects in Buildings, Design, Cinema, Painting, Sculpture, Celant, G., (Ed.), Skira, Milano, p. 75-79.

Mininni, M., 2015. Nuove società e inerzia dello spazio aperto: Matera e gli esiti di un progetto riformista agro-urbano. Territorio, 72, Franco Angeli, Milano, p. 59-66.

Mumford, L., 1999. La cultura della città. Rosso, M., Scrivano, P., (Eds.), Edizioni di Comunità, Torino.

Musatti, R., 1955. Matera, città contadina. Comunità, p. 33.

Piccinato, L., 1955. Matera, i Sassi, i nuovi borghi ed il Piano regolatore. Urbanistica, 16(5).

Pontrandolfi, A., 2002. La vergogna cancellata. Matera negli anni dello sfollamento dei Sassi. Edizioni Altrimedia Eumenidi, Matera.

Poretti, S., 2002. L'INA casa. Il cantiere e la costruzione. Gangemi Editore, Roma.

Quaroni, L., 1955. Il paese dei barocchi. Casabella Continuità, p. 208

Quaroni, L., 1981. Matera e La Martella: piani e progetti. La città fisica. Laterza, Bari.

Raguso, A., 2010. Matera dai Sassi ai Borghi 1952/1964. Un modello di gestione del territorio. Altrimedia Edizioni, Matera.

Reichlin, B., 2001. Figures of Neorealism in Italian Architecture (Part 1), Grey Room, 5, p. 78-101.

Rogers, E.N., 1954. Le responsabilitá verso la tradizione. Casabella Continuità, 202, p. 1-3.

Sabatino, M., 2013. Orgoglio della modestia. Architettura moderna italiana e tradizione vernacolare. Franco Angeli, Milano.

Tafuri, M., 1964. Ludovico Quaroni e lo sviluppo dell'Architettura moderna in Italia. Comunità, Milano.

Tafuri, M., 2002. Storia dell'architettura italiana. 1944-1985. Einaudi Editori, Torino.

Talamona, M., 2001. Dieci anni di politica dell'Unrra Casas: dalle case ai senzatetto ai borghi rurali nel Mezzogiorno d'Italia (1945-1955). Il ruolo di Adriano Olivetti. Costruire la città dell'uomo. Adriano Olivetti e l'urbanistica, Olmo, C., (Ed.), Edizioni di Comunità, Torino, p. 173-204. 